Acta Universitatis Sapientiae, Philologica, 8, 2 (2016) 79-92

DOI: 10.1515/ausp-2016-0019

\title{
Cultural Interchangeability? Culture-Specific Items in Translation ${ }^{1}$
}

\author{
Zsuzsanna AJTONY \\ Sapientia Hungarian University of Transylvania (Miercurea Ciuc, Romania) \\ Department of Humanities \\ ajtonyzsuzsa@yahoo.com
}

\begin{abstract}
This paper summarizes the results of the translation work carried out within an international project aiming to develop the language skills of staff working in hotel and catering services. As the topics touched upon in the English source texts are related to several European cultures, these cultural differences bring about several challenges related to the translation of realia, or culture-specific items (CSIs). In the first part of the paper, a series of translation strategies for rendering source-language CSIs into the target language are enlisted, while the second part presents the main strategies employed in the prepared translations.
\end{abstract}

Keywords: realia, translation strategy, intercultural communication, cultural sensitivity

\section{Introduction}

This paper summarizes the challenges and the results of the translation work carried out by the Sapientia team within an international Erasmus+ project for Strategic Partnership called "Key Skills for European Union Hotel Staff" (Project No 2014-1-HR01-KA2014-007224; implemented in the period of 2014-2016), aiming to develop the language skills of staff working in hotel and catering services. In this presentation, I would like to focus on the translation of extralinguistic cultural references (ECRs) or realia which were found as the most challenging part of the translation work. For this purpose, in the first part of the paper, I would like to give a general presentation of the project, followed by a brief summary of the main translation strategies enlisted by the literature of the domain related to the translation of culture-specific references. The main part of the paper consists of the presentation of a series of examples which display the

1 This study was conducted with the financial support of the Erasmus+ project entitled "Key Skills for European Union Hotel Staff” (Project No 2014-1-HR01-KA2014-007224). 
most imposing problems encountered during the translation work. The paper ends with the conclusions drawn from this demanding linguistic experience.

\section{Presentation of the project}

The ongoing project in which the Department of Humanities of Sapientia University is involved is an international Erasmus+ project for Strategic Partnership called "Key Skills for European Union Hotel Staff” (Project No 2014-1-HR01-KA2014-007224; implementation period 2014-2016), aiming to develop the language skills of staff working in hotel and catering services. In this project, six partner institutions from six countries are collaborating: Tourism and Catering School Dubrovnik (Croatia), Primrose Publishing (UK), Ekonomska šola Murska Sobota (Slovenia), IPSSA Nino Bergese (Italy), Sapientia University, campus of Miercurea Ciuc (Romania), and Turiba University (Latvia). It addresses the specific objectives of the Erasmus+ programme in the field of education and training. Among the objectives of the project, the following might be mentioned: 1) to improve the level of key competences and skills (namely, employability skills and language competences), with particular regard to their relevance for the labour market (tourism and hospitality industry) and their contribution to a cohesive society (providing better cultural awareness and increased language competence); 2) improve language teaching/learning and promote EU's broad linguistic diversity. The project is targeted at developing professional language competence in six EU countries in twelve languages (English, Italian, Croatian, Latvian, Slovenian, Romanian, Hungarian, German, French, Russian, Spanish, and Greek) and raising hospitality industry employees' intercultural awareness.

The project is aimed at creating and designing materials that provide hotel staff, trainees, and students with a very extensive range of replies to guests' questions and requests in twelve languages - at the hotel reception, in the hotel restaurants, cafés and bars as well as in other parts of the hotel. On a broader scale, all this has also been designed to become equally valuable to everyone who works in the field of tourism and deals with foreign visitors. The project has also provided ideas and study materials in the above mentioned twelve languages for the hotel management to enable them to deliver information to groups of guests, to make presentations, to promote the hotel, to help staff recruitment, to enhance international collaboration, and to manage the hotel and the staff more efficiently.

The project also provides a wealth of valuable insights into cultural differences between various European countries and the principal countries outside Europe where visitors come from, with in-depth guidance on what one should do and say and what one should avoid doing and saying in different countries and contexts and when talking to foreigners. The first part of the project focuses on designing 
teaching/learning materials for professional language learning in the hospitality industry (CEFR ${ }^{2}$ level A2/B1) in twelve languages. The second part of the project focuses on the development of 6 in-depth modules for English language learning (CEFR level B2/C1) related to work in the tourism and hospitality industry. The project website is available at http://www.language4hotel.eu/.

As mentioned above, at the initial stage of the project implementation, an English-language material was created to help hotel staff, trainees, and students to interact effectively and confidently with guests using a variety of languages. The needs analysis conducted at an earlier stage of the project had shown what different employees in a hotel need in order to deal efficiently and politely with guests using a foreign language. An extensive range of frequently asked guest questions and typical staff replies were developed by the English partner in order to enhance the work of those working at the reception desk and in the restaurant. The material was integrated within three colourful digital maps as well (see figures 1,2 , and 3), representing hotels and their surroundings in three separate imaginary locations: in the rural countryside, by the seaside, and in the mountains, at a ski resort, all three available online (http://www.2clix.eu) and on CDs.

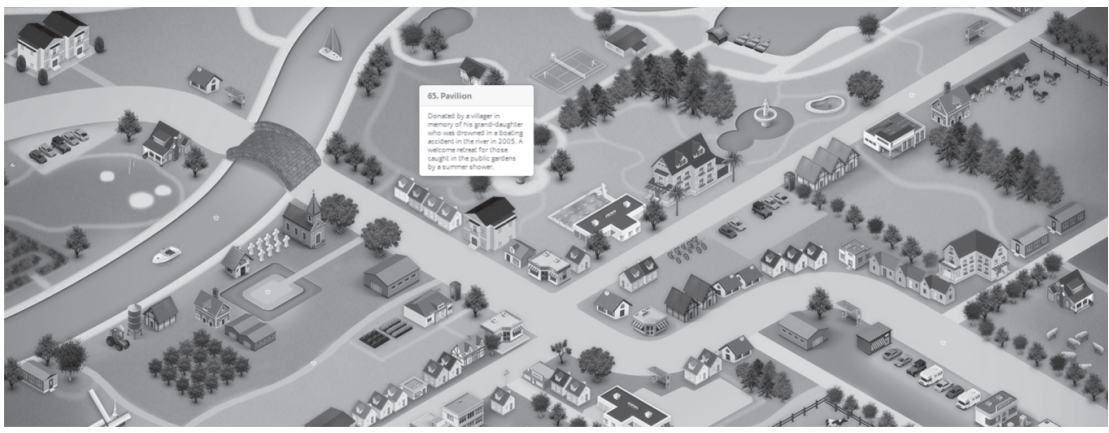

Figure 1. Village map

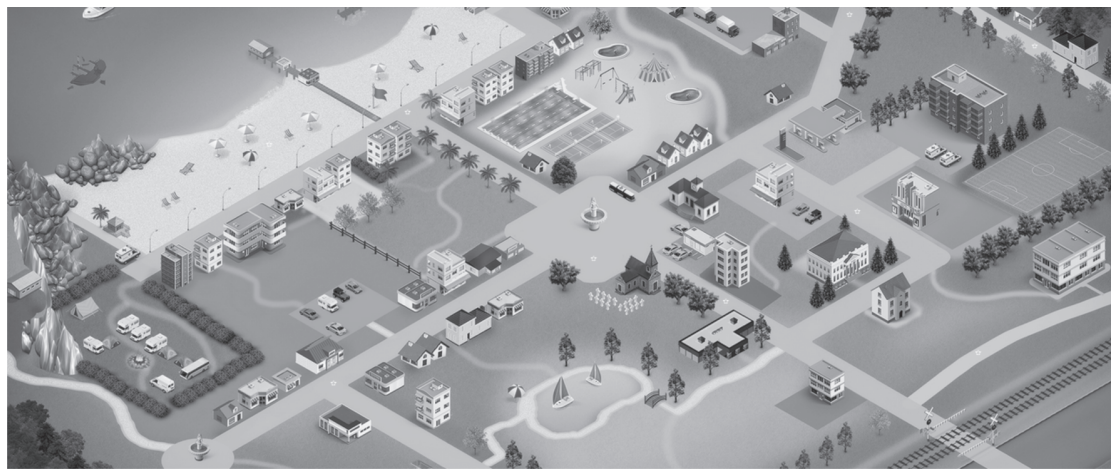

Figure 2. Seaside map

2 Common European Framework of Reference. 


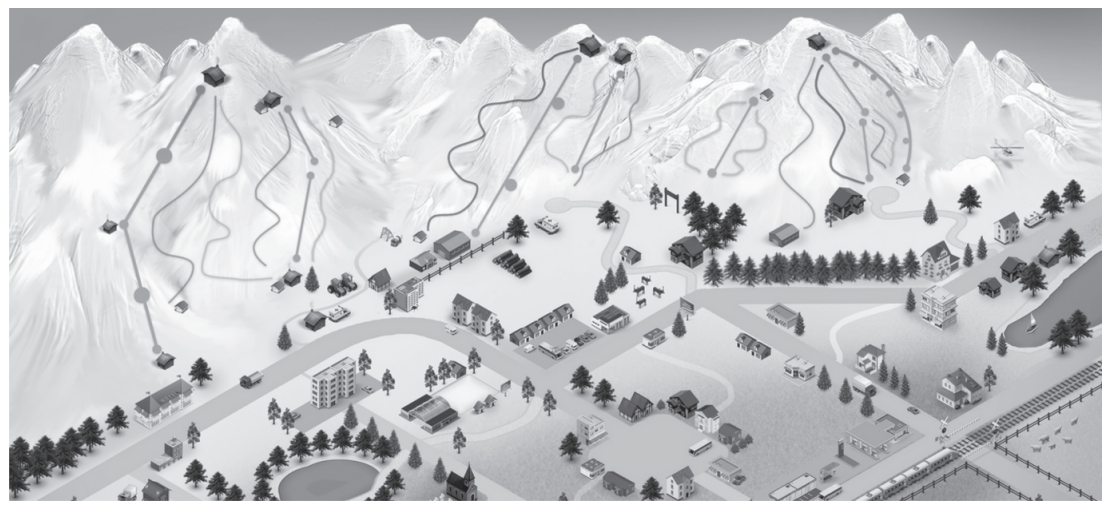

Figure 3. Ski resort map

The materials have also made extensive use of smartphone apps in the twelve languages, easily downloadable and ready to use by both hotel and restaurant staff and by their guests or anybody interested in using them or simply playing with these digital maps or apps (http://2clix.net/frontdesk/).

As mentioned above, within the implementation part of the Front Desk and Restaurant work package, several hundred guest questions and staff replies were created in English. These were translated by the partner institutions into the languages they were responsible for. As Sapientia University is situated in a region where the national language is Romanian and the language spoken by the majority of the local population is Hungarian, our team's task was to translate the English material into these two languages, as well as to translate Hungarian and Romanian materials into English. As the author of this paper was translating mainly into Hungarian, the examples will present EN-HU translations.

\section{Culture, language, translation strategies, cultural interchangeability}

Due to the fact that the source material to be translated belongs to the domain of tourism and hospitality industry, it is highly culture-specific. The cultural differences existing between countries are especially visible in this context as being one of those extralinguistic areas where cultural substitution or transference frequently occur. In order to provide proper translation of cultural terms, the translator needs to be aware of the source culture, recognize the cultural elements in the text, and try to find a proper variant in the target language considering the target audience. The cultural aspects of the translation work are especially emphasized here as well as the translator's task to find the most appropriate technique of conveying these aspects in the target language (James 2002, Stolze 2009). 
In order to analyse the linguistic strategies employed within the translation work carried out within the project, Newmark's definition of “culture” has been taken into account. In his view, culture is "the way of life and its manifestations that are peculiar to a community that uses a particular language as its means of expression" (Newmark 1998: 94). He distinguishes "cultural” from "universal" and "personal" language, especially focusing on the "foreign" cultural words in their narrow sense. In his view, “"cultural' words are easy to detect since they are associated with a particular language and cannot be literally translated”. However, he also enlists several "cultural customs (...) where literal translation would distort the meaning" and [therefore] "a translation may include an appropriate descriptive-functional equivalent” (1998: 95).

There are two distinct attitudes regarding the culture-language relationship. On the one hand, Newmark does "not regard language as a component or feature of culture" (1998: 95). His view is in direct opposition to the one taken by Vermeer who states that "language is part of a culture" (2012: 193). Vermeer's stance implies the impossibility of translation, whereas for Newmark translating the source language (SL) into a suitable form of target language (TL) is part of the translator's role in transcultural communication.

In our view, the success of a translation depends to a large degree on its coherence with the target audience's ("the addressees"') situation, and this stance is especially valid for translations carried out in the domain of tourism, where the skopos (aim) of the translation is to attract the highest possible number of target audience to the region (cf. Reiss \& Vermeer 2014, Nord 1997, among others).

In this paper, I would like to focus on the translation of culture-specific items (CSI) or extralinguistic cultural references (ECRs), particularly on the translation of food and cooking items, names of national dishes, and geographical names that raise the most frequently asked question: "What kind of strategies to apply in their translation?” As Aixelá (1998: 58) claims, these CSIs are "those textually actualized items whose function and connotations in a source text involve a translation problem in their transference to a target text, whenever this problem is a product of the non-existence of the referred item or of its different intertextual status in the cultural system of the readers of the target text”.

Having in mind that food items are considered to be especially culture-sensitive and "are important expressions of national culture" (Newmark 1998: 97), these specific national terms are not interchangeable because they denote mono- or transcultural references that are not to be transferred into the target language. Therefore, the translators in the project have followed the advice given by the scholarly literature in translation studies referring to the translation of realia (see Florin 1993, Tellinger 2003) or other overlapping terms such as "culturebound problems" (Nedergaard-Larsen 1993), "cultural categories” (Newmark 1998), “culture-specific items" (Aixelá 1996, Terestyényi 2011), “allusions” 
(Leppihalme 2001, 2011), and "extralinguistic cultural references" (Pedersen 2007). They have come to the agreement that the names of national dishes should be retained, but in their description universal terms should be employed that might be understood by any foreign speaker.

In the taxonomy of translation strategies, two major ECR transfer strategies can be distinguished: (1) Minimum Change and (2) Intervention. Minimum change includes a further subdivision: (a) the inclusion of the official equivalent into the target text (TT), (b) retention, which means that the original cultural reference is retained, i.e. taken over from the source text (ST) unchanged into the TT, and (c) direct translation. Intervention includes (a) specification (addition and completion), (b) generalization (hyponymy and paraphrase), and (c) substitution (cultural and situational) (taxonomy taken over from Pedersen 2007). (For an earlier discussion of the problems in the translation of realia, see Ajtony 2015.)

\section{Discussion of translation problems}

In the following part of the paper, some problems are highlighted where translators encountered special difficulties. First, the problems related to the translation of national dishes are discussed. Next - closely related to the former topic - , the translation of the food glossary is considered, especially focusing on the items of food which have geographical and, therefore, cultural specificity. Finally, a series of instances from the translation of the Front Desk and Restaurant guest questions and answers are mentioned.

\subsection{Translation of national dishes}

One of the most challenging parts of the translation work consisted of a special aspect of the restaurant- and kitchen-related sentences. This section involved the creation of a short, accurate, and very clear description of fifty national dishes for each of the six partner countries. The list of national dishes was conceived in such a way as to be ideal descriptions a guest needs in order to decide whether or not to order the dish. These descriptions have no recipes and no list of ingredients, but sufficient information for the guest to form a vivid image of the dish. These lists of national dishes were first created in the five partners' languages, re-created in English, and then translated into the other seven languages. As Sapientia is considered to be a Romanian institution in this project, its first language is obviously taken to be Romanian in spite of the fact that our campus is situated in a region with a majority of native Hungarian population. Therefore, the list of national dishes was first created in Romanian, then it was translated / re-created in English, and finally translated into Hungarian. 
In the translation of the names of national dishes, the strategy of retention has been employed, a translation strategy involving minimum changes: i.e. the name of the dish has been retained, only their description was translated into English, and then into Hungarian, employing the strategy of specification (addition and completion). We interpreted the term "national dishes" in a specific way. As Romania is a country where several nationalities coexist, the cuisine of several nations can be found on the menus of restaurants, depending on the region. Consequently, we included not only typical Romanian dishes in the list (see examples 1-3 below) but also typically Hungarian ones (examples 7-10), and even one Armenian dish (example 11). In the following, we shall present different strategies applied in the translation of national dishes, illustrated with examples.

In the case of typically Romanian dishes, the name of the Romanian dish was retained, and its description was translated into English and Hungarian:

(1) Saramură de peşte

(RO) Diferite feluri de peşte fripte pe pat de sare, servite, de regulă, cu mămăligă.

(EN) Several kinds of fish grilled on a bed of salt, usually served with cornmeal porridge.

(HU) Sóágyon sült halfélék puliszkával tálalva.

(2) Tochitură

(RO) Tocăniță de porc sau de vită cu cârnăciori, ceapă şi condimente. Preparat servit cald, alături de mămăligă cu ochiuri şi brânză rasă deasupra.

(EN) Pork or beef stew including sausage, onion, and spices. Served hot, usually with a side-dish of cornmeal porridge topped with fried egg covered in grated cheese.

(HU) Kolbásszal, hagymával és fúszerekkel ízesített disznó- vagy marhapörkölt. Melegen tálalják; köretként puliszkát szolgálnak fel reszelt sajttal megszórt tükörtojással.

(3) Pastramă

(RO) Carne sărată, afumată, uscată, condimentată şi marinată, friptă la cuptor. Preparat servit cald sau rece, în felii subțiri, cu praz şi cartofi prăjiți sau cu mămăligă caldă.

(EN) Salted, smoked, dried, seasoned, and marinated meat baked in the oven. Served hot or cold, in thin slices with leeks and chips or hot polenta.

(HU) Sózott, füstölt, szárított, fúszeres és marinírozott hús sütőben megsütve. Hidegen vagy melegen, vékony szeletekre vágva, póréhagymával és hasábburgonyával vagy meleg puliszkával tálalják.

(4) Papanaş

(RO) Brânză dulce de vaci, prăjită în ulei şi servită cald, presărată cu zahăr pudră şi cu smântână şi dulceață deasupra. 
(EN) Sweet cottage cheese fried in oil and served hot, powdered with caster sugar and topped with cream and jam.

(HU) Melegen tálalt, olajban sült, kristálycukorral meghintett, tejföllel és lekvárral leöntött édes túróból készült édesség.

Secondly, there were examples where the Romanian name of the dish was adopted in Hungarian - with a Hungarian spelling. In these cases, the Romanian name of the dish was retained, but the Hungarian spelling of the Romanian name was also included in the description (see the names written in bold in examples 5 and 6), the same way as it would appear in the menu of a local restaurant.

(5) Mititei (Mici)

(RO) Cârnăciori dintr-un amestec de carne tocată de porc, de vită şi de miel, fripți la grătar. Se servesc cu muştar şi cu pâine, ca gustare caldă sau ca fel principal.

(EN) Grilled sausages of minced pork, veal, and lamb meat mixed together. Served with mustard and bread as a hot starter or main course.

(HU) Miccs. Roston sült, darált disznó-, borjú- és bárányhús keverékből készült apró kolbászkák. Mustárral és kenyérrel, melegen, előételként vagy főfogásként tálalják.

(6) Ciorbă țărănească

(RO) Ciorbă de legume tocate şi fierte, cu carne de porc, servită cald, adesea cu smântână şi cu ardei iute.

(EN) A sour soup consisting of pork and chopped boiled vegetables, served hot, often with cream and chili pepper.

(HU) Parasztcsorba. Disznóhúsból és kockára vágott főtt zöldségekből készült savanyú leves. Melegen, tejföllel és csípős paprikával tálalják.

A third category includes those entries which were taken over from the Hungarian cuisine into the Romanian one, preserving the Hungarian term in the name of the Romanian dish. However, the samples presented below display three different stages: Example 7 renders the Hungarian term via French borrowing (which offers the name a more 'professional' sounding as French is considered to be the language of gastronomy), Example 8 preserves the Hungarian term, while examples 9 and 10 are naturalized borrowings (according to Newmark, the naturalization technique "adapts the SL word first to the normal pronunciation, then to the normal morphology of the TL" (1988: 82). ${ }^{3}$

3 Here, I would like to thank my reviewer for having drawn my attention to the distinction within this category. 
(7) Varză à la Cluj

(RO) Straturi de varză dulce sau murată, amestecate cu straturi de carne de porc tocată. Preparat servit cald, ca fel principal, cu smântână.

(EN) Main course of fresh or pickled white cabbage layered with minced pork. Served hot with sour cream.

(HU) Kolozsvári káposzta. Friss vagy savanyú káposztából készült, darált disznóhússal rétegelt étel. Melegen, tejföllel tálalják.

(8) Vargabéles

(RO) Budincă de tăiței coaptă. Desert tipic unguresc, servit cald sau rece.

(EN) Baked Hungarian noodle-cake dessert served warm or cold.

(HU) Vargabéles. Széles metéltből készült magyar sütemény. Desszertként szolgálják fel, melegen vagy hidegen.

(9) Gulaş

(RO) Gulaş - făcut din bucățele de carne de porc, de vită sau de oaie şi din cartofi tăiați cubulețe, servit ca supă sau ca fel principal.

(EN) Goulash - containing chopped pork, beef or mutton and diced potatoes, served as a soup or main course.

(HU) Gulyás - kockára vágott disznó-, marha- vagy juhhús és felkockázott krumpli. Levesként vagy főfogásként tálalják.

(10) Langoş

(RO) Gogoaşă plată, prăjită în ulei, servită cu smântână, caşcaval ras şi usturoi sau servită dulce, cu gem deasupra.

(EN) Deep-fried dough served with sour cream, grated cheese and garlic, or served sweet, topped with jam.

(HU) Lángos - Bő olajban sült kelt tészta. Tejföllel, reszelt sajttal és fokhagymával vagy édesen, lekvárral leöntve szolgálják fel.

The single typical Armenian dish that was mentioned in our list was "Ciorbă armenească", where in the case of the English translation a general description of the dish can be found, while the Hungarian translation contains the typical Armenian name of the soup:

(11) Ciorbă armenească

(RO) Ciorbă tradițională armeană, făcută din zeamă de carne fiartă şi condimentată cu frunze de pătrunjel.

(EN) Traditional Armenian sour soup made of meat broth and seasoned with parsley leaves.

(HU) Ángadzsábur leves. Hagyományos örmény savanyú leves. Húslevesből készül petrezselyem levéllel ízesítve. 
As the examples above show, several strategies were employed in order to translate this wide variety of Transylvanian dishes. The diversity of the dishes entailed a diversity of translation strategies: mainly the strategy of retention was employed, where the official equivalent of the dish was preserved, with the specific spelling of the target text (see "gulyás" - "goulash" - "gulaş"), but the strategy of intervention (specification, generalization) was also applied.

The following subchapter presents the translation problems encountered in another corpus related to food and cooking, in this case, the glossary, which raised further questions.

\subsection{Glossary of food and cooking items}

Besides the translation of the description of national dishes which presented cultural items that have to rendered with different strategies in the TL (either English or Hungarian), the project also contained a glossary of 213 items of food, which was prepared and translated into 12 languages, among which Hungarian and Romanian. The main headings of this glossary included: vegetables, fish and seafood, meat, cereals, fruit, herbs, spices and nuts, as well as methods of cooking were enlisted. The most challenging part of the translation work included those items which are foreign to the Romanian and/or the Hungarian cuisine, and therefore the TL equivalent was sometimes difficult to find. For the Sapientia team, one of the most interesting parts of this glossary was the list of fish and seafood, which are quite "distant" (both geographically and culturally) for the translators as inhabitants of a mountainous region such as the one where the campus of Miercurea Ciuc is situated. Here is the list of 35 such items in English and their Hungarian translation:

\begin{tabular}{ll}
\hline FISH AND SEAFOOD & HALAK ÉS A TENGER GYÜMÖLCSEI \\
\hline anchovy & szardella \\
\hline carp & ponty \\
\hline catfish & törpeharcsa \\
\hline cod & tôkehal \\
\hline crab & tengeri rák \\
\hline cuttlefish & tintahal \\
\hline eel & angolna \\
\hline gilt-head bream & aranyfejú keszeg \\
\hline haddock & foltos tőkehal \\
\hline hake & tôkkehal \\
\hline halibut & óriási laposhal \\
\hline
\end{tabular}




\begin{tabular}{ll}
\hline FISH AND SEAFOOD & HALAK ÉS A TENGER GYÜMÖLCSEI \\
\hline herring & hering \\
\hline John Dory & kakashal, Szent Péter hala \\
\hline lobster & homár \\
\hline mackerel & makréla \\
\hline monkfish & ördöghal \\
\hline mussel & éti kagyló \\
\hline octopus & polip \\
\hline oyster & osztriga \\
\hline perch & sügér \\
\hline plaice & lepényhal \\
\hline pike & csuka \\
\hline red mullet & vörös márna \\
\hline shrimp & garnélarák \\
\hline salmon & lazac \\
\hline sardine & szardínia \\
\hline sea bream & durbincs, tengeri keszeg \\
\hline scallops & fésúkagyló \\
\hline sea bass & tengeri sügér \\
\hline seaweed & hínár, tengeri moszat \\
\hline skate & rája \\
\hline sole & nyelvhal \\
\hline squid & tintahal \\
\hline whelk & ehetô kürtös csiga \\
\hline &
\end{tabular}

The question is how language teachers or learners, as target groups of this language material, can attend to this list of English and Hungarian equivalents. Obviously, if cultural interchangeability is at stake, it can be claimed that these specific food items will never have the same meaning for a person familiar with the cuisine of the British Isles as for a native Hungarian or Romanian in Transylvania. If such a learner would like to acquire the names of these kinds of fish, they will naturally look them up on an Internet site to check at least their image, and also, if possible, taste them when the occasion arises, in order to be more familiar with them.

\subsection{Translation of Front Desk and Restaurant questions and answers}

The last subchapter of this paper highlights some of the main problems encountered during the translation process of the Front Desk (including the 
Village, Ski, Seaside sections) and Restaurant guest questions and answers mentioned above in Chapter 2, where several hundred typical questions asked by guests and typical answers given by receptionists and restaurant staff had to be translated from English into Hungarian and Romanian. Within this section, the project partners agreed that geographical names (toponyms), personal names, artistic and cultural items should be retained.

In all sections of the Front Desk texts, no equivalent was needed for internationally known cultural terms, such as types of credit cards (MasterCard, Visa, American Express), names of English newspapers (Daily Telegraph), persons' names (e.g. Marianna, Henry, Jacqueline, Maurice). However, common street names, such as Church Street or High Street, were replaced by their Hungarian equivalents (Templom utca, Fó utca), but in the case of Riverside Lane, Chapel Lane, where the Hungarian equivalent would sound less common, the original English name was added in brackets, as a gloss: "Folyópart köz (Riverside Lane)”, "Kápolna köz (Chapel Lane)".

The most specific technical terms could be found within the Ski section, where certain special skiing equipment operating in the imaginary ski resort were translated using the strategies of direct translation and retention: in most cases, the proper name was retained (when it was translatable, it was translated in brackets), while the name of the equipment was translated. For instance:

(12) (EN) What time does the Dragon chair-lift start in the morning?

(HU) Mikor indul reggel a Sárkány (Dragon) székes felvonó?

(13) (EN) The gondola lift is out of action. Should we go on the Horizon drag-lift?

(HU) A gondola felvonó nem múködik. Használjuk inkább a hosszú Horizont síliftet?

(14) (EN) Where is the toboggan-run?

It starts from the top of the Chamois chair-lift.

(HU) Hol van a szánkópálya?

A Zerge (Chamois) székes felvonó felső állomásánál kezdődik.

(15) (EN) Can I have lessons in Telemark skiing?

(HU) Van lehetőség Telemark sítanfolyamra?

(16) (EN) There is a challenging stretch of moguls at the start of the Diabolo run.

(HU) A Diabolo pálya elején van egy nehéz, mogulos szakasz.

\section{Conclusions}

The translation work carried out within the Erasmus partnership project proved to be a really difficult but interesting challenge to work with. As one of the main aims of the project was to decrease the cultural distance between nations of the 
EU and to raise intercultural awareness in the tourism industry, the translators' help was twofold: on the one hand, they carried out a special task of rendering intercultural elements into each others' languages, thus helping future hotel industry staff to make themselves better understood by their guests and trying to minimize the chance of cultural misunderstandings. On the other hand, the translators themselves were acquainted with the great number of new cultural terms they had not been familiar with. The cultural competence of the translators was especially tested in this project, and the results showed that they managed to handle the challenge quite well.

Regarding the proper translation and transferring strategies, it can be claimed that the suitable rendering of culture-specific items in a TL (the transference of realia) gives a "local colour" to the text while retaining cultural names and concepts. As it could be seen both in the translation of national dishes as well as the culture-specific terms in the Front Desk and Restaurant texts, several SL cultural words were borrowed and introduced into the TL. As opposed to the practice noticeable in tourist guidebooks (see Rezaei \& Kuhi 2014), translators tended to domesticate the cultural elements as much as possible. The purpose of this tendency was to make the translated material more user-friendly and more accessible for its target audience, learners, and teachers alike.

\section{References}

Aixelá, Javier Franco. 1996. Culture-specific items in translation. In: Álvarez, Román, M. Carmen-África Vidal (eds), Translation, Power, Subversion, 52-78. Clevedon: Multilingual Matters.

Ajtony, Zsuzsanna. 2015. Dilemmas of cultural mediation: A case study of tourism. Acta Universitatis Sapientiae, Philologica 7(2): 47-58.

Florin, S. 1993. Realia in translation. In: P. Zlateva (ed.), Translation as social action: Russian and Bulgarian perspectives, 122-128. London: Routledge.

James, Kate. 2002. Cultural implications for translation. Translation Journal. http://www3.uji.es/ aferna/H44/Cultural-implications.htm.

Leppihalme, Ritva. 2001. Translation strategies for realia. In: Pirjo Kukkonen, Ritva Hartama-Heinonen (eds), Mission, vision, strategies, values: a celebration of translator training and translation studies in Kouvola, 139-146. Helsinki: Helsinki University Press.

2011. Realia. In: Gambier, Yves, van Doorslaer, Luc (eds), Handbook of translation studies. Vol. 2, 126-130. Amsterdam: John Benjamins.

Nedergaard-Larsen, Birgit. 1993. Culture-bound problems in subtitling. Perspectives: studies in translatology 2: 207-241.

Newmark, Peter. 1988. A textbook of translation. London: Pearson Education. 
Nord, Christiane. 1997. Translating as a purposeful activity. Functionalist approaches explained. Manchester: St. Jerome Publishing.

Pedersen, Jan. 2007. Cultural interchangeability: The effects of substituting cultural references in subtitling. Perspectives: Studies in Translatology 15(1): 30-48.

http://www.researchgate.net/publication/233213421_Cultural_Interchangeability_The_Effects_of_Substituting_Cultural_References_in_Subtitling. Accessed on: 21 April 2015.

Reiss, Katharina-Hans J. Vermeer. 2014. Towards a general theory of translational action. Skopos theory explained. London and New York: Routledge.

Rezaei, Massome-Davud Kuhi. 2014. Strategies employed in translation of tourist guidebooks culture-specific items from Persian into English. Theory and Practice in Language Studies 4(4): 750-757.

Stolze, Radegundis. 2009. Dealing with cultural elements in technical texts for translation. The Journal of Specialized Translation 11: 124-140.

Tellinger, Dusán. 2003. A reáliák fordítása a fordító kulturális kompetenciája szemszögéből [The translation of realia from the perspective of the translator's cultural competence]. Fordítástudomány 5(2): 58-70.

Terestyényi, Enikő. 2011. Translating culture-specific items in tourism brochures. In: Franko, S. (ed.), SKASE Journal of Translation and Interpretation (online) 5(2): 13-23.

http://www.skase.sk/Volumes/JTI06/pdf_doc/02.pdf.

Vermeer, Hans. 2012 [1989]. Skopos and commission in translational activity. In: Venuti, Lawrence (ed.), The translation studies reader, 191-202. London: Routledge. 